\section{SIR JAMES PAGET, BART., F.R.S.}

$\mathrm{THE}$ death of Sir James Paget removes from our midst one of the ornaments of the medical profession. The loss is not an acute one since, though living up till some ten days ago, Sir James has for the last decade taken little active part in professional matters, but still, although the sphere of his activities has been during this period restricted by infirmity, one had evidence from time to time that he was there, using to the best of his strength that cultured mind, which never lost its vigour, for the benefit of those branches of knowledge which he loved so well.

This week's medical papers are so full of the professional attainments of the subject of this notice, and so rich in minute biographical detail, that there remains on these subjects little to be said. Sir James Paget was chiefly known to the world as a great surgeon, who, in addition to his actual professional abilities, exercised a profound charm over his patients. He was for the years he worked actively at St. Bartholomew's the student's model; not only what he did in the wards, but how he did it, served as a type to be imitated. His lectures and demonstrations were eagerly attended, and no note of discordance was there. The medical student, now of academic habits, was apt, in the early teaching days of Paget, to be rowdy, but there was never any disorder at his lectures, his fascinating diction rendering even the details of the most unæsthetic subjects sufficiently attractive to ensure the attention of his class.

Although Sir James Paget's practice as a surgeon, when he was at the height of his vigour, has perhaps never been surpassed, it was to the science of surgery rather than to its art, to its theory rather than to its practice, that he mainly contributed. He was no operating surgeon in the sense of Billroth. His surgery always contained in it an element of philosophy, a projection, so to speak, of his own philosophical spirit. $\mathrm{He}$ was a teacher, and enunciator of principles rather than mere facts.

In these days of what may be termed mathematical biography, one is apt to sum up a man's works, his contributions to knowledge, and regard the sum of them as an accurate measure, if not an actual expression, of his intellectual influence. This is not a fair test of the actual work of Paget. His original work on the catalogue of the Hunterian Collection at the College of Surgeons, and on that of the museum at St. Bartholomew's, his discovery of the trichina spiralis, his description of Paget's disease of the nipple and osteitis deformans, are perhaps the chief examples of his labours sufficiently sharp to wedge themselves through the crude and erratic surface of popular professional recognition. This, however, is no real measure of the man; he learnt from everything and taught from everything. He had the power of impressing the most varied subject-matter with his own philosophical individuality; the subject-matter in 1846 being the flora of Yarmouth; in 1896 , or thereabouts, the medical student; his routine duties as warden at St. Bartholomew's affording to him material for a most valuable essay as to the ultimate fate and chances of success of the medical student.

In Paget's intellectual prime principles of exact science were beginning to be applied to medicine and surgery, such men inter alia as Pasteur, Liebig, Helmoltz, Brücke, \&c., were busy examining with instruments of precision the fundamental phenomena and manifestations of life ; not the least merit of Paget was that he kept well abreast of these stirring times, and gleaned from the purely scientific work of the great masters, facts and principles which he applied to surgery and surgical pathology. In these days of triennial medical congresses one can form but a very poor idea of what it meant in Paget's early days to be well up in conNO. I 576 , VOL. 6I] temporary science. His frequent advice to students to learn German seems now difficult to understand; it would be interesting to inquire how many men there are now who wish they had taken it.

Paget must be regarded, then, as an original teacher more than an original worker or writer; his ideas, perhaps somewhat metamorphosed in accordance with more exact technique, by his pupils, are springing up today on all sides, and will continue to do so. Like all truly great, he vas truly benevolent, and many suggestions and ideas emanating from his mind have seen daylight under the names of his pupils.

\section{F. W. Tunnicliffe.}

\section{NOTES.}

THE Chemical Society's Victor Meyer Memorial Lecture will be delivered by Prof. T. E. Thorpe, President of the Society, on the evening of Thursday, February 8 , at 8.30.

We learn from Science that Prof. William Harkness, astro. nomical director of the U.S. Naval Observatory, retired as Rear-Admiral on December I7, on reaching the age of sixty years. Prof. S. J. Brown has been appointed to succeed him at the Observatory.

A SEVERE earthquake occurred on New Year's day in the province of Tiflis. The greatest amount of damage was done in the district of Achalkalak, in which six villages were completely destroyed and seven others had many houses ruined. Up to the present time, eight hundred dead bodies have been recovered.

WE regret to have to record the death, on January I, after a very short illness, at his residence in Norwood, of Mr. W. T. Suffolk, the Treasurer of the Royal Microscopical Society, in his sixty-ninth year. Though but little known to the general public, and carried out in a very unobtrusive way, his services to microscopical science were great.

THE general manager of the South-Eastern and Chatham Railway, Mr. Alfred Willis, has made arrangements with the Wireless Telegraph and Signal Company for the Marconi system to be used in the course of a few weeks on the company's Royal Mail steamers between Dover and Calais, and also on their Royal Mail steamers between Folkestone and Boulogne. By this arrangement the vessels when in mid-Channel, or half-anhour from either the French or English shores, will have telegraphic communication with either side.

THE Paris correspondent of the Chemist and Druggist remarks :- - Prof. Riche, who was recently succeeded at the Paris School of Pharmacy by Prof. Moissan, was born at Gray (Hautes Saône) in I829, and studied at the Faculty of Sciences and the Polytechnic School. He was appointed assistant professor at the School of Pharmacy in 1859, and professor of inorganic chemistry in 1873 . His principal researches are on tungsten and its compounds. He has done some valuable work at the French Mint in compounding alloys, and is an active and usefu member of the Paris Cuuncil of Hygiene. His successor, M. Moissan, declares that it was in listening to his chemical lecture that he felt his first enthusiasm for the subject and resolved to become a chemist.

SInCE last week's issue we have received the Connaissance des Temps for 1901, the opening year of the new century. We then quoted a statement in the Times that the Paris Observatory "will henceforth in all its publications reckon the day from midnight to midnight." In spite of a suggestion to the contrary made some time ago, both the Nautical Almanac and the Connaissance des Temps have made no change, and the day is reckoned from noon to noon. 